\title{
An Integrative Review of Self-efficacy: What Factors Enhance and Impair It?
}

\author{
RIAS TUSIANAH ${ }^{1}$, CUCU SUTARSYAH $^{2}$, MUHAMMAD SUKIRLAN ${ }^{2}$, RIDWAN RIDWAN ${ }^{3}$, \\ YUNISCA NURMALISA ${ }^{4}$, USASTIAWATY C.A.S ISNAINY ${ }^{5}$, ALBET MAYDIANTORO ${ }^{6}$, \\ M. ARIFKI ZAINARO ${ }^{5}$, TUBAGUS ALI RACHMAN PUJA KESUMA ${ }^{7}$ \\ ${ }^{1}$ Doctor of Education Program, University of Lampung, Bandar Lampung City, INDONESIA \\ ${ }^{2}$ Department of English Education, University of Lampung, Bandar Lampung City, INDONESIA \\ ${ }^{3}$ SMP Negeri 3 Way Pengubuan, Central Lampung Regency, INDONESIA \\ ${ }^{4}$ Department of Civic Education, University of Lampung, Bandar Lampung City, INDONESIA \\ ${ }^{5}$ Department of Nursing Management, Universitas Malahayati, Bandar Lampung City, INDONESIA \\ ${ }^{6}$ Department of Economic Education, University of Lampung, Bandar Lampung City, INDONESIA \\ ${ }^{7}$ Department of Social Science, Institut Agama Islam Negeri (IAIN) Metro, Metro City, INDONESIA
}

Abstract: This paper studies and analyzes self-efficacy with previous empirical research to find out and understand the factors that influence the strengthening and weakening of self-efficacy. The analysis that the authors conducted include the fields of education, health, leadership, and psychology. The sample articles for this study were academic papers obtained from the Google Scholar search engine and other sources including Sage, Routledge (Taylor \& Francis), Elsevier, Springer, Eric, and Scopus. The author uses an integrated review method, a total of 20 papers were analyzed. This study has two conclusions, namely (1) factors such as feelings of fair treatment, well-organized activities, programs designed according to participant characteristics, stress at a manageable level of thinking, appropriate load, sense of expectation, and good experience, can increase selfefficacy, (2) on the contrary, feelings of discrimination, many problems that are difficult to overcome, lack of support, and a burdensome environment can damage self-efficacy.

Key-word: self-efficacy, enhance, impair, integrated review

Received: January 19, 2021. Revised: June 26, 2021. Accepted: July 1, 2021. Published: July 7, 2021.

\section{Introduction}

Self-efficacy is the focus of research in various analyses, such as relationships, predictions, and mediation. Researchers have also recorded it for various subject studies, such as education, management, and health.

In the educational sector and along with the increasing public awareness of the rights to education, teachers will increasingly face new challenges, such as fulfilling children's rights to education for students with special needs. For example, the field of physical education is growing rapidly and a developing amount of learners' teachers who choose physical education as the main choice will meet learners with afflictions in their time to come for their careers of teaching. Selfefficacy is needed in the relationship between skilled studying groups, college belief in university, join efficacy of teachers, and their dedication to learners [1].
With the popularity of the blended system especially during the pandemic, more and more participants are following classes offered on the internet via an open-access platform; however, most of the participants who started this class did not complete it. The mismatch of learner motives and following involvement propounds that self-control due to self-efficacy is a major cause of this shortage of perseverance resulting from self-efficacy [2].

In the health sector, structured desensitization effects alter evasion behavior by creating and reinforcing self-efficacy hopes. Overall elimination of threat anxiety visualized by desensitization treatment resulted in a distinct increase in selfefficacy. Self-efficacy and accomplishment suggest self-efficacy are very accurate predictors of the rate of behavior shift after full desensitization. These discoveries also underpin the view that self-efficacy intercedes anxiety. Process self-efficacy and behavior shift during treatment with a participant model. Self-efficacy is shown to become an 
Rias Tusianah, Cucu Sutarsyah, Muhammad Sukirlan, Ridwan Ridwan, Yunisca Nurmalisa, Usastiawaty C.A.S Isnainy, Albet Maydiantoro, M. Arifki Zainaro, Tubagus Ali Rachman Puja Kesuma

excellent forecast of the amount of improvement in phobic behavior that resulted from mastery of multiple threats at different stages of intervention [3].

Self-efficacy is the essence belief of the basis of person agency nature. Human believe that they can result the intentioned effect and prevent unwanted things by their deeds. Besides, experts introduce collective efficacy. In the collective efficacy, there is a growing interdependence of human functions that exist in the exercise of collective agency nature by means of a shared belief in the power to create influences through shared deed [4].

\section{Aim and Research Question}

This integrative review is conducted to critically review what causes self-efficacy up and down by analyzing the past practices stored in the literature, with the research question: "What factors enhance and impair self-efficacy?" to guide this research.

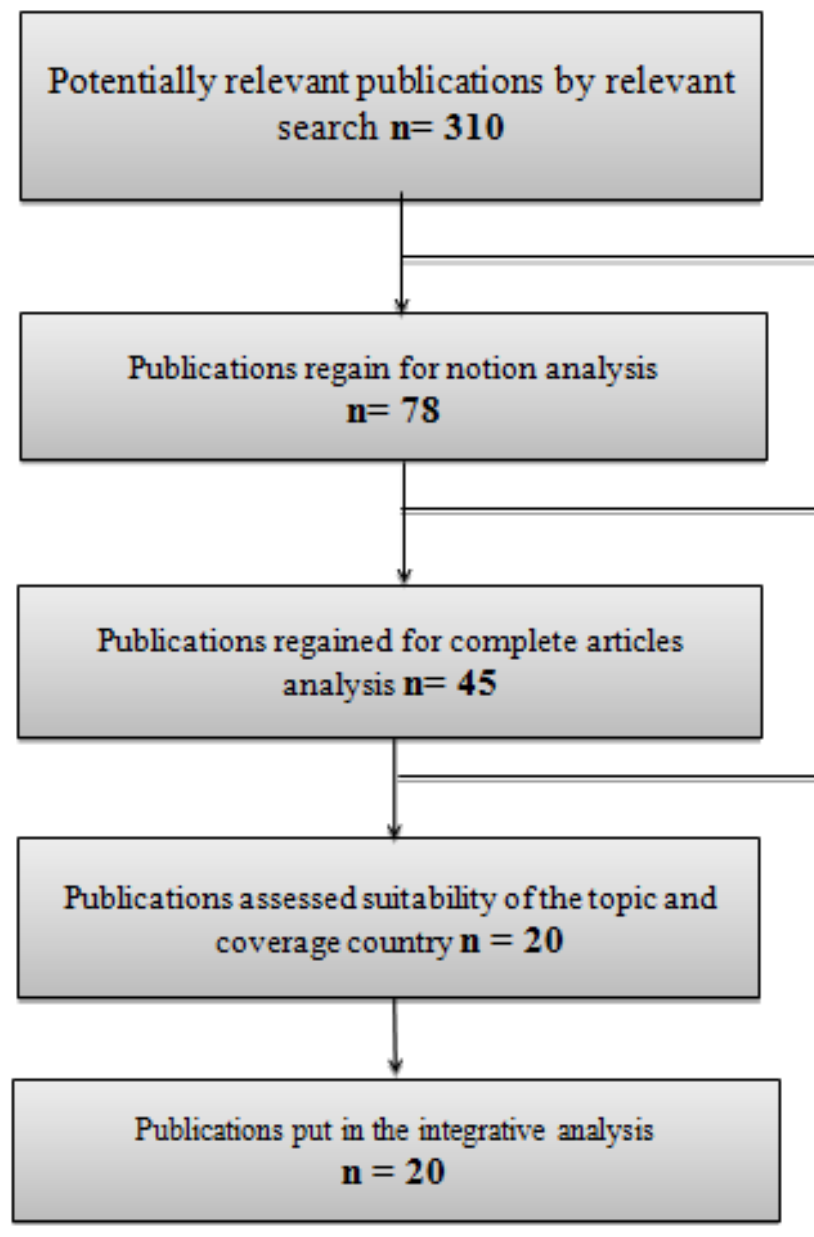

Fig.1: Stages of Learning Choice of Integrative Literature Review

\section{Methods}

An integrative review was done employing the skeleton by Whittemore and Knafl [5] to inspect the documents regarding self-efficacy. The way was selected because it merges the theoretical documents or literature, qualitative and quantitative studies. This way permits for many viewpoints and by turns, allows the discussant to better comprehension the causes. The integrative review way by Whittemore and Knafl [5] Whittemore and Knafl contains of five phases: identification of problem, documents search, data assessment, data analysis, and serving.

\subsection{Search Strategy}

This literature review is about self-efficacy focusing on factors enhancing and impairing it. The process of reviewing this literature begins with a search engine, Google scholar, to search for articles with the keywords "self-efficacy, enhancing and impairing self-efficacy, and experimental". The criteria included in this study are 20 articles selected as in the literature review process flow chart shown

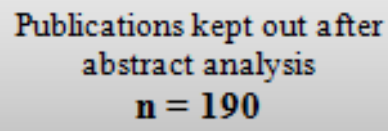

Publications kept out after abstract analysis $\mathbf{n}=190$

Publications kept out after abstract analysis $n=62$
Publications kept out after complete articles analysis $\mathbf{n}=\mathbf{2 9}$ 


\subsection{Screening}

From the quest reported above, 310 articles were identified (see Figure 1 for data quest process). A selecting process get rid of copies and unconnected documents, yielding in 190 documents. The abstracts of these documents were assessed build upon the following inclusion criteria: (a) related to efficacy, (b) published in English. From the 78 abstracts, 62 complete documents were assessed for qualified. Analysis of the complete documents was evaluated built upon quality assessment criteria (see Table 1). Among these cases, 20 articles met the criteria for the integrative review.
M. Arifki Zainaro, Tubagus Ali Rachman Puja Kesuma

\subsection{Quality Assessment}

Articles that meet the requirements are then evaluated for grade making use of the Assessment Tool, which is deliberately made based upon a standard appraisal basis (see Table 1). This allows authors to check the main study deeply and ensure its relevancy and functionality. To increase accuracy, the main study was independently evaluated by two fellows of the analysis team (authors one and two), and differences of opinion fields were discussed. If ambiguity persists, the third team fellows conducted more assessments to come to a final settlement among the analysis team fellows.

Table 1. Quality Valuation categories

1. Does the article include efficacy both affect or affected?

2. Are there any unstated or stated descriptions to make or affect efficacy both self and/or collective-efficacy up or down? 
Table 2. Self-Efficacy in the Research

\begin{tabular}{|c|c|c|c|c|c|}
\hline No & $\begin{array}{c}\text { Author, } \\
\text { country and } \\
\text { Year }\end{array}$ & Title & Method & Sample & Some identified significant result \\
\hline 1 & $\begin{array}{l}\text { Evans, et al. } \\
{[6]}\end{array}$ & $\begin{array}{l}\text { Randomized } \\
\text { Experiments Testing the } \\
\text { Efficacy of Scheduling } \\
\text { Boost in a Massive } \\
\text { Open Online Course } \\
\text { (MOOC) }\end{array}$ & $\begin{array}{l}\text { Survey, experimental } \\
\text { Design, Blocking, } \\
\text { Estimation, and } \\
\text { Covariate Balance }\end{array}$ & $\mathrm{N}=18,043$ & $\begin{array}{l}\text { Random task to treatment had no impact on short-term } \\
\text { involvement and a very important negative effect on long- } \\
\text { term course involvement, persistence, and performance. } \\
\text { A theoretically motivated intervention could interact with a } \\
\text { variety of individual student motivations in ways that may } \\
\text { not be desirable. }\end{array}$ \\
\hline
\end{tabular}




\begin{tabular}{|c|c|c|c|c|}
\hline & & & $\begin{array}{l}\text { breaking down the } \\
\text { variance in teacher } \\
\text { self-perceived efficacy } \\
\text { into two components: } \\
\text { the inter-teacher } \\
\text { component, which } \\
\text { reflects the variance in } \\
\text { some sense of teacher } \\
\text { efficacy across classes, } \\
\text { and the inter-teacher } \\
\text { component, which } \\
\text { reflects relative } \\
\text { variation in the stable } \\
\text { or global component } \\
\text { of self-efficacy. The } \\
\text { analysis was then } \\
\text { extended to investigate } \\
\text { a series of hypotheses } \\
\text { about the sources of } \\
\text { variation at each level } \\
\text { of analysis. }\end{array}$ & $\begin{array}{l}\text { teacher control over their working conditions and } \\
\text { increased opportunities to collaborate with other teachers } \\
\text { can increase their perceptions of self-efficacy. } \\
\text { Nevertheless, given the design of this study, more } \\
\text { research is needed to evaluate the impacts of these } \\
\text { organizational design changes on educators' self-efficacy. } \\
\text { Finally, researcher noted that more research is needed on } \\
\text { the relationship between teachers' sense of efficacy, } \\
\text { teaching practice, and student results. It was different to } \\
\text { previous researchers; the assumption is that this } \\
\text { relationship is complex. The assumption is that a high } \\
\text { sense of accomplishment is required if teachers are to } \\
\text { successfully deal with the uncertainties of classroom } \\
\text { teaching. However, the specific way in which self- } \\
\text { efficacy results in effective teaching for different groups } \\
\text { of students remains to be determined. }\end{array}$ \\
\hline 3 & $\begin{array}{l}\text { Moolenaar, et } \\
\text { al. [8] }\end{array}$ & $\begin{array}{l}\text { Teaming up: Linking } \\
\text { collaboration networks, } \\
\text { collective efficacy, and } \\
\text { student achievement }\end{array}$ & $\begin{array}{lll}\text { Quantitative } & \text { survey } & 53 \text { Dutch elementary } \\
\text { methods } & & \text { schools }\end{array}$ & $\begin{array}{l}\text { Well-connected teacher networks are associated with } \\
\text { strong collective teacher efficacy, which by turn supports } \\
\text { learner's achievement. }\end{array}$ \\
\hline 4 & $\begin{array}{l}\text { Nosratinia, et } \\
\text { al. [9] }\end{array}$ & $\begin{array}{l}\text { EFL Learners' Self- } \\
\text { efficacy, Metacognitive } \\
\text { Awareness, and Use of } \\
\text { Language Learning } \\
\text { Strategies: How Are } \\
\text { They Associated? }\end{array}$ & $\begin{array}{l}\text { Preliminary analysis } 143 \text { EFL learners } \\
\text { was carried out to } \\
\text { ensure that there were } \\
\text { no violations of the } \\
\text { assumptions for } \\
\text { normality, linearity, } \\
\text { and homoscedasticity. } \\
\text { The relationship } \\
\text { between GSES, MAI, } \\
\text { and SILL was }\end{array}$ & $\begin{array}{l}\text { Statistical analysis showed that there was a significant } \\
\text { relationship between EFL students' self-efficacy and } \\
\text { metacognitive awareness, self-efficacy, and use of } \\
\text { language learning strategies, and metacognitive awareness } \\
\text { and use of language learning strategies. In addition, the } \\
\text { regression analysis shows that there is a significant } \\
\text { difference between EFL students' self-efficacy and } \\
\text { metacognitive awareness in predicting the use of language } \\
\text { learning strategies by means of metacognitive awareness } \\
\text { entering the model as the best predictor of language }\end{array}$ \\
\hline
\end{tabular}




\section{investigated using the \\ Pearson product- \\ moment correlation \\ coefficient.}

5 Wang, et al. The Self-Ecacy of Survey, ANOVA [10]
Preservice Physical

Education Teachers in

Disabilities Education in

China All 490,289 ma
and 201 females, average aged 21.3 years

learning strategies. It can be concluded that the results obtained can help EFL teachers and educators to remember the benefits of developing students' selfefficacy and metacognitive awareness when dealing with the promotion of language learning strategies in students.

The survey found that (1) perceived social support positively as a measure of self-efficacy among Chinese sports majors facing students with various types of disabilities; APE studies and internships positively affect self-efficacy among Chinese sports majors dealing with students with different types of disabilities, and; (3) The APE study and internships reinforce the influence of perceived social support on self-efficacy among Chinese sports majors who will encounter learners with different types of disabilities.

6 Prabawanto [11]
The enhancement of This study used a students' mathematical quasi-experimental self-efficacy through design with pre-post teaching with response control. metacognitive scaffolding approach
One group consisted of 60 students who taught mathematics with a metacognitive approach, the control group consisted of 58 high, medium, and low students.

Using the average difference test, the two conclusions of this study are: (1) there is a significant difference in the increase in mathematical self-efficacy between students who take the subject with the metacognitive scaffolding approach and students who take the subject with the direct approach, (2) and no significant interaction effect. There is a significant difference between the teaching approach and the level of ability built on the basis of initial mathematical abilities to improve students' mathematical self-efficacy.

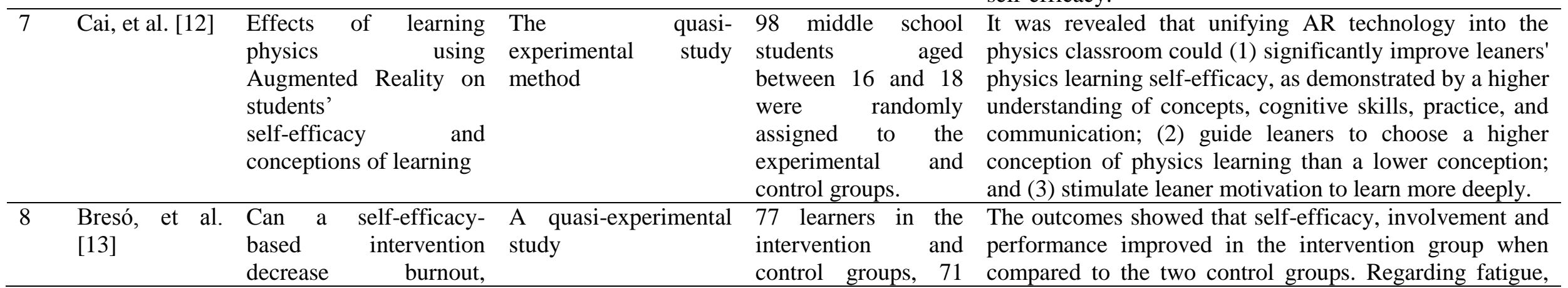




\begin{tabular}{|c|c|c|c|c|c|}
\hline & & $\begin{array}{l}\text { increase engagement, } \\
\text { and } \quad \text { enhance } \\
\text { performance? } \\
\text { A quasi-experimental } \\
\text { study }\end{array}$ & & $\begin{array}{l}\text { learners were } \\
\text { included in the final } \\
\text { analysis, the final } \\
\text { intervention group } \\
\text { consisted of } 21 \\
\text { learners, and the } \\
\text { stress and healthy } \\
\text { control group } \\
\text { consisted of } 23 \text { and } \\
27 \text { learners. }\end{array}$ & $\begin{array}{l}\text { decreases were noted in the intervention and stress control } \\
\text { groups but not in the healthy control groups. The } \\
\text { implications of this study are discussed, along with their } \\
\text { limitations and suggestions for further research. }\end{array}$ \\
\hline 9 & $\begin{array}{l}\text { Malinauskas } \\
{[14]}\end{array}$ & $\begin{array}{l}\text { Enhancing of Self- } \\
\text { Efficacy in Teacher } \\
\text { Education Students }\end{array}$ & 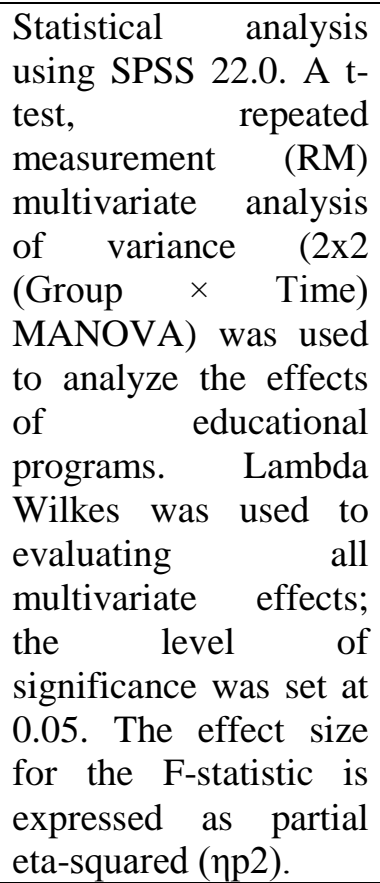 & $\begin{array}{l}\text { Sixty-eight } \quad(68) \\
\text { teacher education } \\
\text { students }\end{array}$ & $\begin{array}{l}\text { To sum up, result that teaching the experimental group } \\
\text { learners education after the training module has increased } \\
\text { self-efficacy more than the same students before the } \\
\text { experiment can be explained by Thompson and } \\
\text { Schlehofer (2011). They claim that people have a } \\
\text { perceived sense of control when they believe that, in } \\
\text { general, control over personal actions is generated and } \\
\text { they personally have the skills to perform those actions } \\
\text { (self-efficacy). } \\
\text { Statistical analysis showed that the training module on } \\
\text { increasing social self-efficacy was effective on teacher } \\
\text { education leaners' general self-efficacy, social self- } \\
\text { efficacy, and teacher self-efficacy beliefs. }\end{array}$ \\
\hline 10 & $\begin{array}{l}\text { Bunkarn, et al. } \\
{[15]}\end{array}$ & $\begin{array}{l}\text { The Outcome of a Self- } \\
\text { Efficacy Enhancement } \\
\text { Program for Cervical } \\
\text { Cancer Screening } \\
\text { among Women in }\end{array}$ & $\begin{array}{l}\text { This study is a quasi- } \\
\text { experimental study to } \\
\text { develop a program to } \\
\text { promote women's self- } \\
\text { efficacy against }\end{array}$ & $\begin{array}{lr}\text { Women aged } 30-60 \\
\text { years } & \text { without } \\
\text { previous } & \text { cervical } \\
\text { cancer } & \text { screening } \\
\text { experience } & \end{array}$ & $\begin{array}{l}\text { In short, self-efficacy improvement programs are intended } \\
\text { for women, taking into account the area, background, and } \\
\text { focus on giving women confidence to overcome barriers } \\
\text { to cervical cancer screening (Chosamata et al., 2015). }\end{array}$ \\
\hline
\end{tabular}




\begin{tabular}{|c|c|c|c|c|c|}
\hline & & $\begin{array}{lr}\text { Phrasaeng } & \text { District, } \\
\text { Suratthani } & \text { Province, } \\
\text { Thailand } & \\
\end{array}$ & $\begin{array}{l}\text { cervical } \\
\text { screening. }\end{array}$ & & \\
\hline 11 & $\begin{array}{l}\text { Ahmad } \\
\text { Sharoni, et al. } \\
{[16]}\end{array}$ & $\begin{array}{l}\text { A self-efficacy } \\
\text { education programme } \\
\text { on foot self-care } \\
\text { behaviour among older } \\
\text { patients with diabetes in } \\
\text { a public long-term care } \\
\text { institution, Malaysia: a } \\
\text { Quasi-experimental } \\
\text { Pilot Study }\end{array}$ & $\begin{array}{l}\text { A quasi-experimental } \\
\text { and post-quasi- } \\
\text { experimental study }\end{array}$ & 52 residents & $\begin{array}{l}\text { These findings suggest that the program is feasible, } \\
\text { acceptable, and effective in improving the foot care } \\
\text { behavior of older diabetic patients. Based on these } \\
\text { findings, educational programs built on self-efficacy } \\
\text { theory would assist and facilitate study planning in a } \\
\text { larger population of elderly with diabetes living in long- } \\
\text { term care institutions using RCTs. }\end{array}$ \\
\hline 12 & $\begin{array}{l}\text { Bandura and } \\
\text { Adams [3] }\end{array}$ & $\begin{array}{l}\text { Analysis of Self- } \\
\text { Efficacy Theory of } \\
\text { Behavioural Change }\end{array}$ & $\begin{array}{l}\text { Subjects whose social, } \\
\text { recreational, and } \\
\text { vocational activities } \\
\text { are detrimentally } \\
\text { exposed to chronic } \\
\text { snake phobia recruited } \\
\text { through advertising } \\
\text { placed in newspapers } \\
\text { serving metropolitan } \\
\text { and suburban areas } \\
\text { community.. }\end{array}$ & $\begin{array}{l}\text { They ranged in age } \\
\text { from } 19 \text { to } 57 \text { years } \\
\text { with a } \\
\text { mean age of } 31 \text { years }\end{array}$ & $\begin{array}{l}\text { This article tells the results of two experimental tests of } \\
\text { the self-efficacy theory of behavior change. The study one } \\
\text { investigated the hypothesis that systematic desensitization } \\
\text { effects change avoidance behavior by creating and } \\
\text { reinforcing personal efficacy expectations. The complete } \\
\text { subtraction of arousal anxiety to the threat visualized by } \\
\text { desensitization treatment resulted in a distinct increase in } \\
\text { self-efficacy. As it is hoped, microanalysis of the } \\
\text { suitability between self-efficacy and performance reveal } \\
\text { self-efficacy to be a very accurate predictor of behavior } \\
\text { change assessment after complete desensitization. These } \\
\text { findings also support the view that self-efficacy mediates } \\
\text { arousal anxiety. The study two investigated the process of } \\
\text { efficacy and behavior change during treatment with a } \\
\text { participant model. Self-efficacy was shown to be a } \\
\text { superior predictor of the number of behavioral } \\
\text { improvement phobias obtained from the mastery of some } \\
\text { of the threats at different phases of treatment. }\end{array}$ \\
\hline 13 & Mwansa [17] & $\begin{array}{l}\text { School } \\
\text { Peadership Style and } \\
\text { Teacher's Self-Efficacy } \\
\text { in High and Low } \\
\text { Achieving Schools in }\end{array}$ & $\begin{array}{l}\text { A quantitative and } \\
\text { non-experimental } \\
\text { design, survey. MLQ } \\
\text { and Teacher Self- } \\
\text { Efficacy } \quad \text { Beliefs }\end{array}$ & $\begin{array}{l}18 \text { school, principals } \\
211\end{array}$ & $\begin{array}{l}\text { Findings from the Chikankata District study indicate that } \\
\text { those who are elected to school leaders as school } \\
\text { principals will improve their ability to influence student } \\
\text { performance if they use more transformational leadership } \\
\text { styles and lower transactional leadership. The use of the }\end{array}$ \\
\hline
\end{tabular}




\begin{tabular}{|c|c|c|c|c|c|}
\hline & & Chikankata, Zambia & $\begin{array}{l}\text { (TSEB). SPSS was } \\
\text { used to analyze data, } \\
\text { bivariate descriptive, } \\
\text { independent sample t- } \\
\text { test, canonical } \\
\text { correlation, and } \\
\text { descriptive } \\
\text { discriminant function } \\
\text { analysis to determine } \\
\text { the relationship } \\
\text { between leadership } \\
\text { style, teacher self- } \\
\text { efficacy, and their } \\
\text { effect on student } \\
\text { achievement. }\end{array}$ & & $\begin{array}{l}\text { same leadership style will increase the influence on } \\
\text { teacher self-efficacy. }\end{array}$ \\
\hline 14 & $\begin{array}{l}\text { Antoniou, et } \\
\text { al. [18] }\end{array}$ & $\begin{array}{l}\text { Occupational stress in } \\
\text { mainstream and special } \\
\text { needs primary school } \\
\text { teachers and its } \\
\text { relationship } \\
\text { with self-efficacy }\end{array}$ & $\begin{array}{l}\text { Software SPSS V.25 } \\
\text { for Windows is used to } \\
\text { get the mean standard } \\
\text { deviation or median } \\
\text { and interquartile range } \\
\text { for normal or non- } \\
\text { normal data } \\
\text { distribution, t-test to } \\
\text { check to get the Mann } \\
\text { Whitney U test for } \\
\text { non-parametric data, } \\
\text { Spearman rho } \\
\text { correlation with P- } \\
\text { values on a 2-tailed } \\
\text { test and significance at } \\
\text { p<.05. }\end{array}$ & $\begin{array}{l}\text { The sample consisted } \\
\text { of } 501 \text { teachers ( } 412 \\
\text { women and } 89 \text { men) }\end{array}$ & $\begin{array}{l}\text { The findings indicate that stress factors specific to } \\
\text { teachers include favouritism of government and school } \\
\text { administration, time pressure and student character, } \\
\text { increased student, resources, and equipment, and support } \\
\text { from parents and the community. In addition, general } \\
\text { school teachers report higher levels of stress and higher } \\
\text { levels of self-efficacy compared to teachers with special } \\
\text { educational needs. Individual variables have also been } \\
\text { shown to have an effect on teacher stress and self- } \\
\text { efficacy. }\end{array}$ \\
\hline 15 & $\begin{array}{l}\text { Kossowska } \\
\text { and Łaguna } \\
{[19]}\end{array}$ & $\begin{array}{l}\text { Personality, Job } \\
\text { Resources, and Self- } \\
\text { Efficacy as Predictors of } \\
\text { Volunteer Engagement }\end{array}$ & $\begin{array}{l}\text { Descriptive } \quad \text { and } \\
\text { correlation } \quad \text { between } \\
\text { researches variables, } \\
\text { multivariate }\end{array}$ & $\mathrm{N}=165$ were & $\begin{array}{l}\text { The results of the hierarchical regression analysis showed } \\
\text { that awareness, skill variation, and self-efficacy were } \\
\text { statistically key predictors of volunteer involvement. This } \\
\text { suggests that the effects of awareness and skill diversity }\end{array}$ \\
\hline
\end{tabular}




\begin{tabular}{|c|c|c|c|c|c|}
\hline & & $\begin{array}{l}\text { in Non-Governmental } \\
\text { Organizations }\end{array}$ & $\begin{array}{l}\text { hierarchical regression } \\
\text { analysis asked to fill } \\
\text { out a questionnaire } \\
\text { that can be accessed } \\
\text { online. }\end{array}$ & & $\begin{array}{l}\text { on volunteer participation were mediated by volunteer } \\
\text { self-efficacy. }\end{array}$ \\
\hline 16 & Lee, et al. [1] & $\begin{array}{l}\text { A multilevel analysis of } \\
\text { the impact of a } \\
\text { professional learning } \\
\text { community, faculty trust } \\
\text { in colleagues and } \\
\text { collective efficacy on } \\
\text { teacher commitment to } \\
\text { students }\end{array}$ & $\begin{array}{l}\text { Statistical analysis: } \\
\text { factor analysis with } \\
\text { varimax rotation for } \\
\text { EFA regression. A } \\
\text { randomized online } \\
\text { teacher questionnaire } \\
\text { survey }\end{array}$ & $\begin{array}{l}33 \text { elementary } \\
\text { (Grades 4-6) and } \\
\text { secondary (Grades } 7- \\
9) .22 \text { teachers from } \\
33 \quad \text { schools, the } \\
\text { response rate of } 73 \% \\
(480) \text { teachers. }\end{array}$ & $\begin{array}{l}\text { PLC factors including shared learning and application and } \\
\text { supportive structures, and faculty trust factors in coworkers } \\
\text { and collective teacher efficacy can importantly and } \\
\text { positively explain the school-level variance of teacher } \\
\text { commitment to students. Another PLC factor, shared and } \\
\text { supportive leadership, was not identified as a significant } \\
\text { predictor of teacher commitment to students in the Chinese } \\
\text { language environment. }\end{array}$ \\
\hline 17 & $\begin{array}{l}\text { Goertz-Dorten, } \\
\text { et al. [20] }\end{array}$ & $\begin{array}{l}\text { Efficacy of an } \\
\text { Individualized } \\
\text { Computer-Aassisted } \\
\text { Social Competence } \\
\text { Training Program for } \\
\text { Children With } \\
\text { Oppositional Defiant } \\
\text { Disorders/Conduct } \\
\text { Disorders }\end{array}$ & $\begin{array}{l}\text { Research protocol } \\
\text { (ClinicalTrials.go, } \\
\text { NCT02143427), } \\
\text { Children receiving } \\
\text { treatment with ScouT. } \\
\text { Data were collected at } \\
\text { three assessment } \\
\text { points: 1) pre1 } \\
\text { (beginning of the 8- } \\
\text { week waiting phase), } \\
\text { 2) pre2 (end of the 8- } \\
\text { week waiting phase } \\
\text { and immediately } \\
\text { before the start of the } \\
\text { 16-week care phase), } \\
\text { and 3) post (at the end } \\
\text { of the intervention). }\end{array}$ & $\begin{array}{l}\mathrm{N}=50 \quad(\text { Fifty } \\
\text { children aged } 6-12)\end{array}$ & $\begin{array}{l}\text { No significant changes occurred for any of the outcome } \\
\text { variables during the waiting phase. During treatment, } \\
\text { most of the parent-rated outcome measures (including the } \\
\text { main outcome measures) showed a significant reduction, } \\
\text { which was stronger than the change in the waiting phase. } \\
\text { Most of the self-assessed outcome measures also showed } \\
\text { a significant reduction during treatment, but a stronger } \\
\text { reduction than in the waiting phase was only found for } \\
\text { aggressive peer-related behaviour. Computer-facilitated } \\
\text { social skill training appears to be an effective CBT } \\
\text { intervention for children with aggressive peer-related } \\
\text { behaviour. }\end{array}$ \\
\hline 18 & $\begin{array}{l}\text { Wright, et al. } \\
{[21]}\end{array}$ & $\begin{array}{l}\text { Enhancing Self-Efficacy } \\
\text { and Performance: An } \\
\text { Experimental } \\
\text { Comparison } \\
\text { Psychological }\end{array}$ & $\begin{array}{l}\text { The in-subject design } \\
\text { assessed each } \\
\text { individual across } 2 \\
\text { trials for } 3 \text { different } \\
\text { PET. The intergroup }\end{array}$ & Participants $(\mathrm{N}=96)$ & $\begin{array}{l}\text { Iinstructional self-statements enhance performance better } \\
\text { than imagery, modelling, goal setting, and feedback plus } \\
\text { motivation and knowledge of outcomes. Motivational } \\
\text { auditory feedback improved SE the most. Increased SE } \\
\text { change scores were associated with increased performance }\end{array}$ \\
\hline
\end{tabular}


Techniques design assessed the differences between PETs paired with each other for 3 similar new assignments difference scores across tasks after controlling for age, gender, achievement motivation, and self-esteem.

Some sources of SE may be more influential than others on SE and performance improvements. This study provides partial support for the SE resources proposed by Bandura's socio-cognitive theory with verbal persuasion but not representative experiences that enhance SE. Asad [22] having Children used. Diagnosed with Autism Spectrum Disorder research design was used.

A total of 60 mothers with ASD children aged 4-12 years were selected from the Lahore Hospital.

The results indicated that there was a significant positive

relationship between resilience and expectation. However, resilience and expectancy did not have a significant relationship with self-efficacy. Multiple hierarchical regression analysis showed that self-efficacy was not predicted by resilience and expectation. The findings imply the importance of considering the sociodemographic characteristics of mothers raising children with ASD to better comprehensions their sense of selfefficacy.

\begin{tabular}{|c|c|c|c|c|}
\hline 20 & Schunk [23] & $\begin{array}{l}\text { Enhancing Self-Efficacy } \\
\text { and Achievement } \\
\text { through Rewards and } \\
\text { Goals: Motivational and } \\
\text { Informational } \\
\text { Effects }\end{array}$ & $\begin{array}{l}\text { The experimental, } 33 \text { children were } \\
\text { ANCOVA, valuable F- taken from } 2 \\
\text { ratio was further elementary schools } \\
\text { analyzed using the } \\
\text { Newman-Keuls } \\
\text { multiple comparison } \\
\text { test (Kirk, 1968). }\end{array}$ & $\begin{array}{l}\text { The center of research is on rewards and goals that depend } \\
\text { on performance connected to children's task motivation, } \\
\text { self-efficacy, and skilled performance. Children lacking in } \\
\text { sharing skills received sharing and problem-solving } \\
\text { guides. One, some children are offered awards based on } \\
\text { their actual appearance (awards only); two, others are } \\
\text { pursuing proximal performance goals (goals only); and } \\
\text { children in the third condition receive rewards and goals } \\
\text { (rewards + goals). Although the three experimental } \\
\text { treatments yielded equally rapid problem solving during } \\
\text { training, combining rewards with the goal of producing } \\
\text { the highest divisional self-efficacy and performance. }\end{array}$ \\
\hline
\end{tabular}




\subsection{Analysis}

The twenty articles selected came from the United States of America, Pakistan, Australia, Germany, Hong Kong, Poland, Greece, Zambia, Malaysia, Thailand, Lithuania, Spain, China, Indonesia, Iran, and the Dutch. The authors put them in one table (see Table 1) to get an understanding of the results and conclusions contained in the article. Furthermore, the authors compile the articles build upon research in the fields of study. Build upon the results of the assessment, there are 4 fields, namely education, health, leadership, and psychology. The final step in the analysis is to report findings. Below are the outcomes, followed by the discussion.

\section{Results and Discussion}

The results obtained from a review of 20 articles led to the study of four categories of areas related to influencing efficacy.

\subsection{Education Practices}

A person who follows learning tends to experience various events. Some events make him/her find something he/she needs or otherwise find something that actually makes him/her feel surprised and creates a feeling of uncertainty. Someone who has the initiative generally tends to have a good level of efficacy [24]. However, it is necessary to have appropriate handling efforts for the learners so that their efficacy is maintained; and increasing efficacy is the goal of learning participation.

A study in the Massive Open Online Course (MOOC) presents the results that random assignment has an effect on continued participation in the continuation of the courses. Furthermore, it has a negative effect on learning participation for the long term. Bad effects also occur on student persistence and learning performance. This happens because the intervention carried out is motivated merely on a theoretical basis; in fact, it can be responded to in various forms of behavior by students. The negative reaction of these students was not what this study explored [6].

In another study, the statistical analysis showed that there was that there was a relation between the efficacies of students as learners of English as a language. The link is between metacognitive awareness and learning strategies. In addition, the calculated regression analysis to see metacognitive awareness as a predictor turned out that metacognitive awareness acts as a good predictor in language learning. Therefore it can be said that efficacy can grow and develop well in students who learn when the teacher is wise in determining learning strategies [9].

The behavior of teachers in Indonesia and Indonesians in general often stereotypes the oaring in black and white, good and bad, as well as high and low. Teachers should be free from this kind of behavior. Teachers should always put forward the good hopes that will happen.

It seems that this kind of dichotomous behavior occurs in other parts of the world as well. A research finding warns educators or anyone else to be wise: don't just dichotomize. This dichotomy also occurs in the aspect of efficacy, including teacher efficacy. It turns out that teacher efficacy is also dichotomized: high and low. What factors put teacher efficacy high and low? These factors include curriculum differentiation, teacher specialization build upon the subject matter, and the character of the curriculum that is age-adjusted $[7,17]$.

After searching more deeply the research found that teachers who had high efficacy worked with high performing students as well. Meanwhile, teachers who work with students who have more learning rights are directly proportional to the teacher's difficulty in helping their students to succeed in learning. It was also found that teachers with high efficacy found themselves difficulty maintaining high self-efficacy when working with assignments in low-track classes.

There needs to be a concerted effort to make reforms at the school organizational level and focus on maintaining teacher efficacy in order to further enhance it so that subject teachers are successful and are directly proportional to student success. Research evidence shows that encouraging teacher autonomy over their working conditions and teachers collaborating with other teachers can increase their perceptions of self-efficacy. All of which contribute to changes in the design of the school organization.

This connection should make us realize that this relationship is complex. However, we may assume that a high sense of accomplishment is required if teachers are to be successful in overcoming the complex interrelationships of teaching that occur in the classroom. To reveal that, the specific way in which self-efficacy, as a result, can be felt in effective teaching for various groups of students needs to be mutually agreed upon [7].

It was explained that collaboration in a wellconnected teacher network would form a strong collective teacher efficacy. This strong community 
efficacy, in turn, supports learner accomplishment. Collective efficacy can sustain teacher selfefficacy. Community efficacy can be obtained from (1) tailored physical education to support positive social relations as an act of self-efficacy. [25] Apprenticeship in adjusted physical education affects self-efficacy positively. (3) Adapted physical education and apprenticeship strengthen the influence of communal underpin on selfefficacy in learners primary in physical education to deal with students with various types of disabilities [10].

Mathematics is still seen today as a difficult subject. However, the use of media or methods can affect students' self-efficacy. A study with statistical calculations using the mean difference test obtained two conclusions: an important difference in improving numerical self-efficacy between learners who take courses with the metacognitive scaffolding approach and learners who take courses with a direct approach, and teaching approach and ability level build upon early mathematics ability do not interact to increase students' numerical self-efficacy [11].

The use of certain methods was able to increase students' self-efficacy. As the example was the use of the method by combining with technology. This study suggests that combining AR technology for physics learning is able to (1) increase learners' self-efficacy is very meaningful. This statement is demonstrated by a high level of conceptual understanding, cognitive competencies, application, and communication; (2) able to lead learners to the mastery of a great height concept of physics; and (3) able to motivate learners to learn more deeply [12].

Techniques for involving students in learning or known to active students also increase selfefficacy. Through the involvement of students, self-efficacy and accomplishment developed in the intervention group when contrasted to the managed group. When students are involved, learning barriers such as anxiety will slowly disappear and the performance of low-thinking skills turns into higher-thinking skills. This can be understood because of the learning process [13].

The use of carefully prepared teaching materials can also increase self-efficacy. This is obtained from experiments. Students who take mathematics subjects with a scaffolding metacognitive approach and students who take subjects with a direct approach experience an increase in efficacy [11]. The learning module is able to control student behavior. This means that a good module that is written and structured in an attractive, easy-to-read manner can contribute well to student efficacy. So that people who have their own sense of control have the skills to apply it to self-efficacy. Statistical analysis declared that training modules on increasing social self-efficacy were effective on teacher education students' common self-efficacy, social self-efficacy, and teacher self-efficacy beliefs [14].

\subsection{Health Practices}

Everyone makes an effort to contribute to life. However, to be able to contribute requires good self-condition. Meanwhile, a healthy him/herself is supported by many factors. One of them is selfefficacy. Self-efficacy is very effective in overcoming various problems, including health. Curing a disease is not enough only from medical but also non-medical factors: self-efficacy. For this reason, the treatment of the patient's disease should also be accompanied by increasing the patient's self-efficacy. Many patients are afraid of pretreatment programs, as happened to women with cervical cancer. However, several factors need to be controlled in a self-efficacy improvement program including considering their region of origin, background, and focus on giving women the confidence to overcome barriers to cervical cancer screening $[15,26]$.

The power of this research is that elderly diabetics live jointly in an organization and constantly make a social call by internal health care providers to allow discussion of the process of modifying foot care behavior itself. Respondents can share their experiences about the program and sustain one another for continuity. It is expected that in the time to come, the findings from this pilot research can assist in the application of a selfefficacy theory-based foot care behavior education program. A similar educational program involving a larger sample of elderly patients with diabetes in public long-term care institutions is required in the Malaysian setting. Continued sustain from universities and the state institutions with the necessary resources to help elderly patients with diabetes increase patient health status [16].

In addition, two studies reported their findings from 2 experimental analyses of the self-efficacy theory of conduct shift. One study concluded that anxiety relief is due to overall sensitization of the threat increased self-efficacy. Microanalysis becomes a very correct forecaster of the rate of behavior shift after full desensitization of selfefficacy and performance. These discoveries also sustain the perspective that self-efficacy arbitrates anxiety. The second trial inquiries into the efficacy 
process and behavior shift during treatment. The conclusion is that self-efficacy has been shown to be a superior forecaster of the increase in phobic behavior obtained from the mastery of some threats at various stages of handling up [3].

\subsection{Leadership Practice}

Teacher efficacy was also found to be influenced by what they experienced. Some of the influencing factors are stress, favoritism from the ruler and school management, time insistence, the bad personality of students, limited resources, and devices, also minimal assistance from parents and the community. Individual variables have also been exposed to influence educator stress and selfefficacy [18].

Other research in the field of leadership has shown that hierarchical regression analysis shows that awareness, competence variation, and selfefficacy are statistically important forecaster of volunteer involvement. This suggests that the effect of awareness and skill variation on volunteer involvement is arbitrated by volunteer self-efficacy [19].

Leadership practices in an organization in higher education also affect effectiveness. Programs organized or supported by the leadership can affect the efficacy of lecturers. As well as the ranking and professional development of lecturer organizations or lecturers 'associations, including joint learning and its application as well as conditions and factors supporting lecturers' belief in colleagues and community efficacy of lecturers. These factors can explain the differences in the level of the organization towards the commitment of lecturers to students significantly and positively [1].

\subsection{Psychology Practices}

In the field of psychological studies, efficacy is also important to get attention. Efforts to increase effectiveness through computer treatment for behavioral disorders have been carried out. Measurements were made by measuring the outcome for the 8 weeks waiting for stage compared to the next treatment phase, 16 weekly kids meetings, and 2 parental psychological education touches at the start of therapy, with multilevel modeling. The main result is hostile behavior towards friends by the child's parents. Further result measures included parent evaluations and patient self-reports of hostile and prosocial conduct. No important changes occurred for any of the outcome variables during the waiting phase. During therapy, most of the result measures assessed by parents indicated an important reduction, which was higher than the change in the waiting stage. This means that the proliferation of self-efficacy requires stages and processes. At the stage of waiting for the measurement results are lower than the measurement results. Generally, the self-evaluation result measures also indicated an important reduction during therapy, but a higher reduction than in the waiting stage was only found for hostile peer-related conduct. Computerfacilitated social skills exercise comes up to be a successful CBT interference for kids with hostile peer-related conduct [20].

This is a study with the aim of finding out what factors are better at increasing self-efficacy. The factors offered are self-instruction, self-image, goal setting, good feedback, motivation, and knowledge of results. The study discovered that teaching self-disclosure increases accomplishment better than imagery, modeling, goal setting, and feedback plus motivation and knowledge of outcomes. Motivational auditory feedback best increases self-efficacy. Increased self-efficacy shift scores were associated with developed accomplishment, not the same scores across tasks after managing for age, sex, performance motivation, and self-esteem. Some sources of selfefficacy might be more affected than others on selfefficacy and accomplishment enhancement. This study gives partial support for the sources of selfefficacy advanced by Bandura's socio-cognitive theory with verbal persuasion but not representative experiences that enhance selfefficacy [21].

This research involved mothers in raising their children. The outcomes of this research show that there is an important good connection between resilience and hope but resilience and expectation do not have an important connection with selfefficacy. Multiple hierarchical regression studies showed that resilience and expectation did not forecast self-efficacy. That is, it is necessary to consider the socio-demographic features of mothers raising children with ASD to better comprehend their sense of self-efficacy [27].

The focus of this research was on rewards and goals that depended on performance related to children's task motivation, self-efficacy, and competence accomplishments. Children lacking in sharing competencies received sharing and problem-solving instructions. Condition 1 was that several kids were offered awards based on their true appearance (awards only); condition 2 pursued proximal accomplishment goals (goals only), and in condition 3 the kids received both rewards and 
goals (reward + goal). Even though, the three experimental handlings resulted in equally fast problem solving during training, combining rewards with the goal of producing the highest divisional self-efficacy and performance [28].

\section{Conclusion}

The authors, from an integrated literature review, examined what enhances and impairs self-efficacy, came to two main conclusions: (1) factors such as feelings of fair treatment, well-organized activities, programs designed according to participant characteristics, stress at a manageable level of thinking, appropriate load, sense of expectation, and good experience, can increase self-efficacy, (2) on the contrary, feelings of discrimination, many problems that are difficult to overcome, lack of support, and a burdensome environment can damage self-efficacy.

\section{References:}

[1] J. C.-k. Lee, Z. Zhang, and H. Yin, "A multilevel analysis of the impact of a professional learning community, faculty trust in colleagues and collective efficacy on teacher commitment to students," Teaching and teacher education, vol. 27, no. 5, pp. 820-830, 2011.

[2] R. Baker, B. Evans, and T. Dee, "A randomized experiment testing the efficacy of a scheduling nudge in a Massive Open Online Course (MOOC)," AERA Open, vol. 2, no. 4, p. $2332858416674007,2016$.

[3] A. Bandura and N. E. Adams, "Analysis of self-efficacy theory of behavioral change," Cognitive therapy and research, vol. 1, no. 4, pp. 287-310, 1977.

[4] A. Bandura, "Exercise of human agency through collective efficacy," Current directions in psychological science, vol. 9, no. 3, pp. 75-78, 2000.

[5] R. Whittemore and K. Knafl, "The integrative review: updated methodology," Journal of advanced nursing, vol. 52, no. 5, pp. 546-553, 2005.

[6] B. J. Evans, R. B. Baker, and T. S. Dee, "Persistence patterns in massive open online courses (MOOCs)," The Journal of Higher Education, vol. 87, no. 2, pp. 206-242, 2016.

[7] S. W. Raudenbush, B. Rowan, and Y. F. Cheong, "Contextual effects on the self- perceived efficacy of high school teachers," Sociology of Education, pp. 150-167, 1992.

[8] N. M. Moolenaar, P. J. Sleegers, and A. J. Daly, "Teaming up: Linking collaboration networks, collective efficacy, and student achievement," Teaching and teacher education, vol. 28, no. 2, pp. 251-262, 2012.

[9] M. Nosratinia, M. Saveiy, and A. Zaker, "EFL learners' self-efficacy, metacognitive awareness, and use of language learning strategies: How are they associated," Theory and Practice in Language Studies, vol. 4, no. 5, pp. 1080-1092, 2014.

[10] Y.-S. Wang, L. Liu, X.-W. Wei, and M. E. Block, "The Self-Efficacy of Preservice Physical Education Teachers in Disabilities Education in China," Sustainability, vol. 12, no. 18, p. 7283, 2020.

[11] S. Prabawanto, "The enhancement of students' mathematical self-efficacy through teaching with metacognitive scaffolding approach," in Journal of Physics: Conference Series, 2018, vol. 1013, no. 1.

[12] S. Cai, C. Liu, T. Wang, E. Liu, and J. C. Liang, "Effects of learning physics using Augmented Reality on students' self- efficacy and conceptions of learning," British Journal of Educational Technology, 2020.

[13] E. Bresó, W. B. Schaufeli, and M. Salanova, "Can a self-efficacy-based intervention decrease burnout, increase engagement, and enhance performance? A quasi-experimental study," Higher Education, vol. 61, no. 4, pp. 339-355, 2011.

[14] R. K. Malinauskas, "Enhancing of SelfEfficacy in Teacher Education Students," European Journal of Contemporary Education, vol. 6, no. 4, pp. 732-738, 2017.

[15] O. Bunkarn, K. Kusol, and T. Eksirinimit, "The Outcome of a Self-Efficacy Enhancement Program for Cervical Cancer Screening among Women in Phrasaeng District, Suratthani Province, Thailand," Asian Pacific Journal of Cancer Prevention: APJCP, vol. 21, no. 7, p. 2075, 2020.

[16] S. K. Ahmad Sharoni, H. Abdul Rahman, H. S. Minhat, S. Shariff-Ghazali, and M. H. Azman Ong, "The effects of self-efficacy enhancing program on foot self-care behaviour of older adults with diabetes: A randomised controlled trial in elderly care facility, Peninsular Malaysia," PloS one, vol. 13, no. 3, p. e0192417, 2018. 
[17] P. Mwansa, "School Principal's Leadership Style and Teacher's Self-Efficacy in Highand Low-achieving Schools in Chikankata, Zambia," Andrews University, 2020.

[18] A.-S. Antoniou, V. Efthymiou, F. Polychroni, and O. Kofa, "Occupational stress in mainstream and special needs primary school teachers and its relationship with self-efficacy," Educational Studies, pp. $1-18,2020$.

[19] M. Kossowska and M. Łaguna, "Personality, job resources, and self-efficacy as predictors of volunteer engagement in nongovernmental organizations," Journal for Perspectives of Economic Political and Social Integration, vol. 24, no. 1, pp. 69-89, 2018.

[20] A. Goertz-Dorten et al., "Efficacy of an individualized computer-assisted social competence training program for children with Oppositional Defiant Disorders/Conduct Disorders," Frontiers in Psychiatry, vol. 10, 2019.

[21] B. J. Wright, P. D. O'Halloran, and A. A. Stukas, "Enhancing self-efficacy and performance: an experimental comparison of psychological techniques," Research quarterly for exercise and sport, vol. 87, no. 1, pp. 36-46, 2016.

[22] M. Kanwal and S. Asad, "Resilience, Hope, and Self-Efficacy in Mothers having Children Diagnosed with Autism Spectrum Disorder," 2018.

[23] D. H. Schunk, "Enhancing self-efficacy and achievement through rewards and goals: Motivational and informational effects," The Journal of Educational Research, vol. 78, no. 1, pp. 29-34, 1984.

[24] C. Niven, E. Moran, A. Hill, C. McVey, and A. McGee, "Self-esteem, self-efficacy and locus of control in young people attending a secondary school health initiative: final report on the evaluation of the Health Club within Drumcahpel High School," 2019.

[25] N. Permendikbud, "24. Kompetensi Inti dan Kompetensi Dasar Pelajaran pada Kurikulum 2013 pada Pendidikan Dasar dan Pendidikan Menengah," Kompetensi Inti dan Kompetensi Dasar Pelajaran pada Kurikulum 2013 pada Pendidikan Dasar dan Pendidikan Menengah, 2016.

[26] M. S. Chosamata, "Determinants to Utilization of Cervical Cancer Screening Among Women Aged 30-45 Years in Blantyre District Malawi: A Comparison of
Urban and Rural Areas," Mahidol University, 2015.

[27] M. Kanwal and S. Asad, "Resilience, Hope, and Self-Efficacy in Mothers having Children Diagnosed with Autism Spectrum Disorder."

[28] D. H. Schunk, "Self- efficacy perspective on achievement behavior," Educational psychologist, vol. 19, no. 1, pp. 48-58, 1984.

\section{Conflict of Interest:}

We declare there is no conflict of interest in the writing of this article.

\section{Contribution of Individual Authors to the Creation of a Scientific Article (Ghostwriting Policy) Author Contributions:}

Rias Tusianah, Cucu Sutarsyah, and Muhammad Sukirlan conducted research on the gaps between previous research and parts that had not been investigated and supervised the preparation of the draft article until the article was finished.

Ridwan Ridwan and Yunis Nurmaliza drafted the article and made it completed.

Usastiawaty C.A.S Isnainy, Albet Maydiantoro, M. Arifki Zainaro, and Tubagus Ali Rachman Puja Kesuma were the comparisons in the critical discussion of the articles that were compiled.

\section{Sources of Funding for Research Presented in a Scientific Article or Scientific Article Itself}

This article was not funded by any third party and had no any sponsor of it.

\section{Creative Commons Attribution License 4.0 (Attribution 4.0 International, CC BY 4.0)}

This article is published under the terms of the Creative Commons Attribution License 4.0 https://creativecommons.org/licenses/by/4.0/deed.e n_US 